\title{
Lichen planus pigmentosus and association with autoimmune diseases: A case-control study
}

\section{Monia Youssef', Ines Lahouel', Mouna Korbi', Yosra Soua', Hela Marmouch², Hayet Akkari' ${ }^{1}$, Meriem Mohamed ${ }^{1}$, Hichem Belhajali', Asma Belghith ${ }^{3}$, Jameleddine Zili'}

\author{
${ }^{1}$ Dermatology Department, Fattouma Bourguiba Hospital, University of Monastir, Tunisia, ${ }^{2}$ Endocrinology Department, \\ Fattouma Bourguiba Hospital, University of Monastir, Tunisia, ${ }^{3}$ Community Medicine Department, Fattouma Bourguiba \\ Hospital, University of Monastir, Tunisia
}

Corresponding author: Dr Ines Lahouel, E-mail: lahouel.iness@gmail.com

\begin{abstract}
Background: Studies on the co morbidities seen with lichen Planus Pigmentosus (LPP) are limited. Aims: We sought to determine the prevalence of auto immune diseases (AD) associated with LPP. Methods: A total of 30 patients with LPP and 30 age and sex matched controls were examined. Both groups were evaluated for the presence of AD using physical examination and immunological tests. Results: We collected 30 LPP patients. There were 9 men and 21 women. Prevalence of $\mathrm{AD}$ was higher in LPP patients (40.0\%) than in the control group (3.3\%). LPP was significantly associated with $\mathrm{AD}$, the age and gender adjusted $\mathrm{OR}$ was 22.9; P: 0.005. Twelve patients had an associated AD. There was no statistically significant difference between the group with ADs and without ADs concerning the sex, the age of onset of the disease, the extent of the lesions and the evolution. The immunological tests were positive in only one patient. Limitations: This study was performed in a little sample with a geographically restricted population. Conclusion: We found a frequent association of LPP with ADs. We suggest that autoimmunity might be a pathogenic factor of LPP.
\end{abstract}

Key words: Lichen planus pigmentosus; Autoimmune diseases; Case-control study

\section{INTRODUCTION}

Lichen planus pigmentosus (LPP) is an uncommon variant of lichen planus (LP), characterized by the insidious onset of dark brown macules in sunexposed areas and flexural folds with or without slight pruritus $[1,2]$. It was originally reported from India, but it tends to occur also in other racial and ethnic groups such as Latin Americans, Middle Eastern population, Japanese and Koreans [3-5].

The epidemiologic and physiopathologic characteristics of LPP have not yet been defined. LPP has rarely been described in association with other diseases. The autoimmune pathogenesis of LPP is a controversial subject. No clear association between LPP and auto immune diseases (AD) exists. In our clinical experience, we have observed that patients with LPP often have an AD. A careful review of literature did not find studies that specifically address the prevalence of ADs in patients with LPP. Therefore, we realized this study with a purpose to determine the prevalence of $\mathrm{AD}$ in patients with LPP.

\section{MATERIALS AND METHODS}

\section{Study Design}

A case-control study was performed to assess the prevalence of AD in patients with LPP. The patients and controls were matched on age and sex, and recruited over a 6- year period (2011-2016).

\section{Patients}

We aimed to enroll, consecutively, all patients with a diagnosis of LPP who were admitted to the clinics of

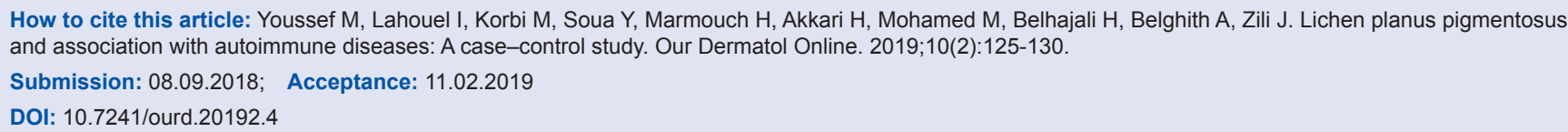


the dermatology department of Monastir hospital in Tunisia.

Inclusion criteria for cases were the presence of largely asymptomatic bluish / blackish brown, macules, distributed mainly on the face, neck and upper extremities. The histological criteria were: (a) epidermal changes: minimal change in epidermal thickness; keratinocyte apoptosis; and vacuolar degeneration of the basal cell layer and (b) dermal changes: presence of band like or perivascular lymphohistiocytic inflammatory infiltrate; scattered melanophages; and melanin incontinence. 30 patients with a diagnosis of LPP were enrolled as the patient group.

\section{Controls}

The control group consisted of 30 age and sex matched individuals (Table 1). The controls were selected among patients with skin diseases other than LPP (chronic pruritus with no specific lesions). The source population for cases and controls was the same.

\section{Collection of Data}

All cases and controls were examined by a dermatologist who registered demographic, biometric and other relevant data on a case report form.

The age of onset, duration of the disease, site of onset of pigmentation, associated symptoms and family history were recorded.

The information was also obtained regarding any related external factors (such as drug intake prior to the onset or use of cosmetics), associated auto immune diseases, cutaneous diseases or other systemic diseases.

A record was made for the morphology and distribution of lesions, extent of lesions, and mucosal, hair and nail involvement.

For all patients and controls, laboratory tests were performed including complete blood count (CBC), sedimentation rate $(\mathrm{SR})$, blood sugar test (BS), antinuclear antibodies (ANA), anti thyroglobulin

Table 1: Distribution of cases and controls

\begin{tabular}{lccc}
\hline & Cases $(\mathbf{n}=\mathbf{3 0})$ & Controls $(\mathbf{n}=\mathbf{3 0})$ & $\mathbf{p}$ \\
\hline Gender $(\%)$ & & & \\
Man & $9(30 \%)$ & $9(30 \%)$ & 1 \\
Woman & $21(70 \%)$ & $21(70 \%)$ & 1 \\
Mean age (years) & $37.6+-16.4$ & $38.5+-15.3$ & 0.82 \\
\hline
\end{tabular}

(C) Our Dermatol Online 2.2019 antibodies ( $\mathrm{TgAb}$ ), anti-thyroid peroxidase antibodies (TPOAb) and serology tests for hepatitis B and C.

The age of onset of the disease, the sex, the site of early lesions, the extent of the lesions, the inversus type, were compared between the two groups of LPP patients with and without ADs, in order to establish if there is or not any factors that may influence this association.

\section{Statistical Analysis}

Statistical analysis was performed on the Software Statistical Package for the Social Sciences (SPSS 21). For between-group comparisons, the independent samples t-test was used for normally distributed continuous variables and Pearson chi-squared test or Fisher exact test was used for nominal data where appropriate. Multiple logistic regressions were performed to calculate the odds ratio (OR) and 95\% confidence interval (CI) after adjusting for age and gender. The statistical significance was fixed with $\mathrm{p}$ inferior to 0.05 .

\section{RESULTS}

The study included 30 cases and 30 controls. For patients, there were 9 men and 21 women $(\mathrm{M} / \mathrm{F}=0.42)$ and the average age at onset was 37.6 years (range 6-68 years). There were 3 children (1 aged 6 years, 2 aged 13 years). The duration of the disease ranged from 1 month to 10 years. Six $(20 \%)$ patients reported mild pruritus. There was no history of previous inflammatory process on the affected areas for all the patients. A causal relationship with drugs, recent sun exposure, cosmetics or trauma were not identified for all patients. Family history of a similar skin disorder was negative in all the 30 patients.

The clinical pattern of pigmentation within LPP patients was mostly diffuse. The face and trunk (Fig. 1) were the commonest sites affected. Inversus type of LPP was seen in seven patients $(23.3 \%)$ with most of them localized in the axillae (Fig. 2). Mucosal lesion (oral involvement) was noticed in one patient. The palms, soles, scalp and nails were spared in all patients.

Skin biopsies were performed from all the patients. Most of the patients had overlapping features of the two patterns (pattern of inflammatory infiltrate and superficial perivascular pattern), with predominance of one of them. Melanin incontinence and melanophages 
were constant findings in all cases (Fig. 3). Hyperkeratosis was marked in 11 (36.6\%).

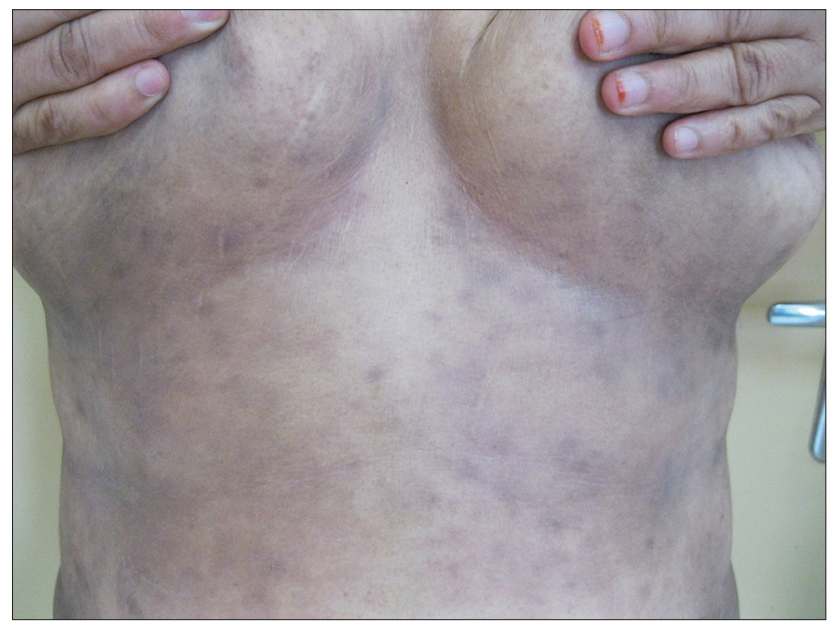

Figure 1: Brown macules localized at the trunk.

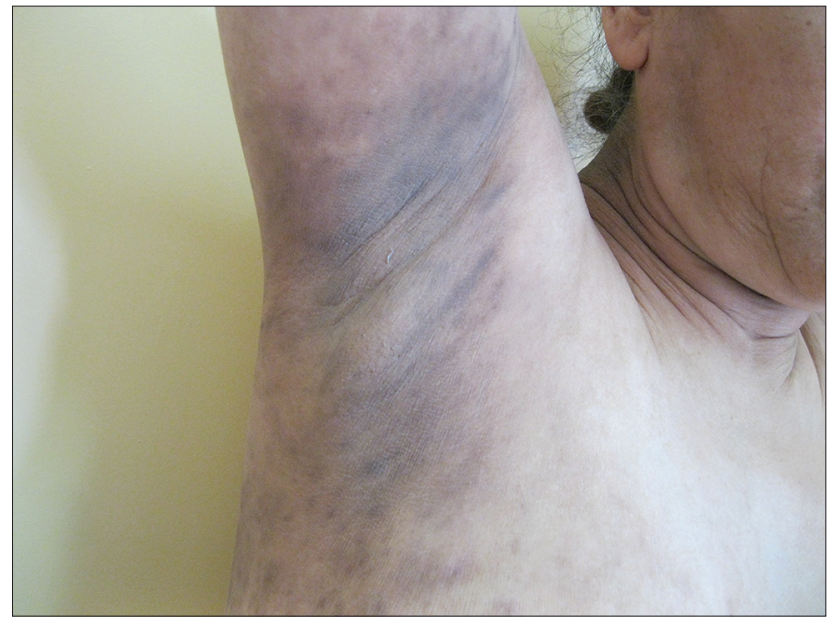

Figure 2: Inversus subtype of lichen planus pigmentosus: brown macules in the axillary fold.

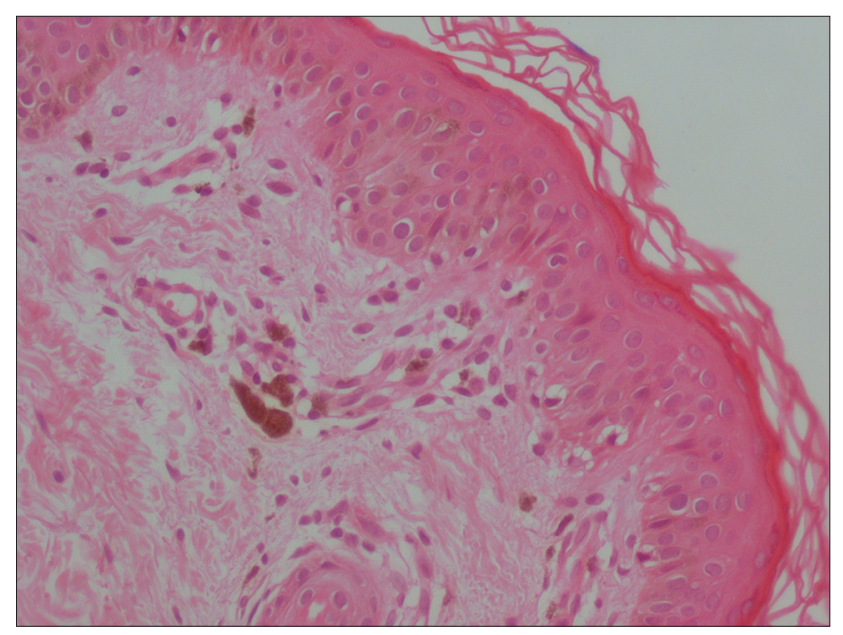

Figure 3: Melanin incontinence and melanophages in the upper dermis (H \& E, ×200).
Prevalence of AD was higher in LPP patients (40.0\%) than in the control group (3.3\%). LPP was significantly associated with AD, the age and gender adjusted OR was 22.9; CI 95\%: 2.62-199.82; P: 0.005 (Table 2).

Twelve patients (40\%) with AD were collected. No significant difference was observed in the extent of lesions in groups with and without AD.

Six patients were diabetic (three patients had diabetes type 1 (DTl) and three patients had Latent Autoimmune Diabetes in Adults (LADA). Three patients had chronic inflammatory bowel diseases (one patient had Crohn's disease, one patient had ulcerative colitis and one patient had lymphocytic colitis). The patient who had lymphocytic colitis had also hypothyroidism. One patient had rheumatoid arthritis, one patient had anti phospholipid antibody syndrome and one patient had Gougerot Sjogren syndrome.

The diagnosis of AD preceded LPP in 9 cases, was made simultaneously with LPP in 2 patients (LADA, autoimmune thyroiditis). One patient developed LADA one year after the diagnosis of LPP.

For all patients the CBC, SR were within normal limits. Hepatitis B and C serology tests were negative for all patients.

The recommended immunological tests were positive in only one patient, who had rheumatoid arthritis. In fact, ANA, anti-nucleosome antibodies, anti $\mathrm{TgAb}$ and anti TPO Ab were significantly positive $(\mathrm{TPOAb}=93 \mathrm{UI} / \mathrm{ml}, \mathrm{Tg} \mathrm{Ab}=390 \mathrm{UI} / \mathrm{ml}, \mathrm{ANA}=1 / 800$, anti nucleosome $\mathrm{Ab}=222 \mathrm{UI} / \mathrm{ml}$ ) while the patient was asymptomatic and had no previous history for lupus nor dysthyrodism.

There were no significant differences regarding the serum levels of CBC, SR, ANA, TgAb, TPOAb and Hepatitis $\mathrm{B}$ and $\mathrm{C}$ serology tests between cases and controls ( $\mathrm{P}=1,049,1,1$ and 1 respectively).

The results of the characteristics of patients with AD are summarized in Table 3.

Table 2: Association with $A D$ for cases and controls

\begin{tabular}{|c|c|c|c|c|c|}
\hline & \multicolumn{2}{|c|}{ Association with AD } & \multirow[t]{2}{*}{$\mathbf{p}$} & \multirow[t]{2}{*}{ ORa* } & \multirow[t]{2}{*}{$\mathrm{Cl} 95 \%$ (ORa) } \\
\hline & Positive & Negative & & & \\
\hline Cases & $12(40 \%)$ & $18(60 \%)$ & 0.005 & 22.86 & $2.63-199.83$ \\
\hline Controls & 1 (3.3\%) & 29 (96.7\%) & & & \\
\hline
\end{tabular}

ORa*: Age and sexe adjusted OR 
Table 3: Clinical, histological, and therapeutic features of patients with LPP associated to AD

\begin{tabular}{|c|c|c|c|c|c|c|}
\hline Sex/age & Duration & Associated AD & Site & Histological examination & Treatment & Course \\
\hline $\mathrm{F} / 29$ & 3 months & DT 1 & Thigh & $\begin{array}{l}\text { Perivascular lymphohistiocytic infiltrate, } \\
\text { pigmentary incontinence, keatinocyte } \\
\text { necrosis }\end{array}$ & $\begin{array}{l}\text { Topical } \\
\text { betamethasone }\end{array}$ & $\begin{array}{l}\text { No } \\
\text { improvement }\end{array}$ \\
\hline $\mathrm{M} / 36$ & 2 months & DT 1 & Face, axillary folds & $\begin{array}{l}\text { Hypergranulosis, melanin incontinence, } \\
\text { perivascular lymphohistiocytic infiltrate }\end{array}$ & $\begin{array}{l}\text { Topical } \\
\text { betamethasone }\end{array}$ & Aggravation \\
\hline $\mathrm{F} / 54$ & 4 months & LADA & $\begin{array}{l}\text { Face, abdomen, axillary } \\
\text { folds }\end{array}$ & $\begin{array}{l}\text { Hyperkeratosis, hypergranulosis, } \\
\text { Band-like lymphocytic infiltrate }\end{array}$ & $\begin{array}{l}\text { Topical } \\
\text { betamethasone }\end{array}$ & $\begin{array}{l}\text { No } \\
\text { improvement }\end{array}$ \\
\hline$F / 62$ & 3 months & LADA & $\begin{array}{l}\text { Back, } \\
\text { Upper and lower limbs }\end{array}$ & $\begin{array}{l}\text { Thining of the epidermis, hyperkeratosis, } \\
\text { pigmentary incontinence, perivascular } \\
\text { lymphohistiocytic infiltrate }\end{array}$ & $\begin{array}{l}\text { Topical } \\
\text { betamethasone }\end{array}$ & $\begin{array}{l}\text { No } \\
\text { improvement }\end{array}$ \\
\hline $\mathrm{F} / 56$ & 2 months & LADA & Back & $\begin{array}{l}\text { Hyperkeratosis, pigmentary incontinence, } \\
\text { melanophages }\end{array}$ & $\begin{array}{l}\text { Topical } \\
\text { betametasone }\end{array}$ & $\begin{array}{l}\text { No } \\
\text { improvement }\end{array}$ \\
\hline $\mathrm{F} / 30$ & 4 months & D T 1 & Lower limbs & $\begin{array}{l}\text { hypergranulosis, } \\
\text { Band-like lymphocytic infiltrate, pigmentary } \\
\text { incontinence }\end{array}$ & $\begin{array}{l}\text { Topical } \\
\text { betametasone }\end{array}$ & $\begin{array}{l}\text { No } \\
\text { improvement }\end{array}$ \\
\hline $\mathrm{M} / 30$ & 4 months & $\begin{array}{l}\text { Lymphocytic } \\
\text { colitis+hypothyrodism }\end{array}$ & Trunk & $\begin{array}{l}\text { Hyperkeratosis, hypergranulosis, } \\
\text { Band-like lymphocytic infiltrate, pigmentary } \\
\text { incontinence }\end{array}$ & $\begin{array}{l}\text { Topical } \\
\text { betametasone }\end{array}$ & $\begin{array}{l}\text { Slight } \\
\text { improvement }\end{array}$ \\
\hline$F / 31$ & 6 months & SAPL & Back & $\begin{array}{l}\text { Hyperkeratosis, pigmentary incontinence, } \\
\text { lymphohistiocytic infiltrate, } \\
\text { melanophages }\end{array}$ & $\begin{array}{l}\text { Topical } \\
\text { betametasone }\end{array}$ & $\begin{array}{l}\text { Slight } \\
\text { improvement }\end{array}$ \\
\hline $\mathrm{F} / 68$ & 6 months & Rheumatoid arthritis & $\begin{array}{l}\text { Back, upper and lower } \\
\text { limbs }\end{array}$ & $\begin{array}{l}\text { Hyperkeratosis, hypergranulosis band-like } \\
\text { lymphocytic infiltrate and melanophagia in } \\
\text { the papillary dermis }\end{array}$ & $\begin{array}{l}\text { Topical } \\
\text { betametasone }\end{array}$ & $\begin{array}{l}\text { No } \\
\text { improvement }\end{array}$ \\
\hline $\mathrm{F} / 37$ & 1 year & $\begin{array}{l}\text { Gougerot Sjogren } \\
\text { syndrome }\end{array}$ & $\begin{array}{l}\text { Lower members, } \\
\text { axillary folds }\end{array}$ & $\begin{array}{l}\text { Lichenoid dermatitis, pigmentary } \\
\text { incontinence }\end{array}$ & $\begin{array}{l}\text { Topical } \\
\text { betametasone }\end{array}$ & $\begin{array}{l}\text { No } \\
\text { improvement }\end{array}$ \\
\hline $\mathrm{M} / 52$ & 3 months & Crohn 's disease & Face & $\begin{array}{l}\text { Hyperkeratosis, pigmentary incontinence, } \\
\text { lymphohistiocytic infiltrate, } \\
\text { melanophages }\end{array}$ & $\begin{array}{l}\text { Topical } \\
\text { betametasone }\end{array}$ & $\begin{array}{l}\text { Slight } \\
\text { improvement }\end{array}$ \\
\hline$F / 42$ & 8 months & Ulcerative colitis & $\begin{array}{l}\text { Face, upper and lower } \\
\text { limbs }\end{array}$ & $\begin{array}{l}\text { Keatinocyte necrosis, melanin } \\
\text { incontinence, perivascular } \\
\text { lymphohistiocytic infiltrate, melanophages }\end{array}$ & $\begin{array}{l}\text { Topical } \\
\text { betametasone }\end{array}$ & $\begin{array}{l}\text { Slight } \\
\text { improvement }\end{array}$ \\
\hline
\end{tabular}

\section{DISCUSSION}

Our study is a pilot study and the first study from Tunisia seeking for LPP associated diseases. Our results were in agreement with previous studies from Japan, India and Kuwait regarding the clinico- epidemiologic aspects of LPP [3-6]. Nevertheless, we report a significant association between LPP and ADs (more than the quarter of our patients had associated ADs). This association has not been reported before. Analysis of the prevalence of ADs in patients with or without LPP and possible associated risk factors, particularly sex, age, site of early lesions, extent of lesions, itching and the course after topical corticosteroid, did not show statistically significant differences.

Although the association between LP and ADs is well known, a similar prevalence in LPP patients has not been established. In fact, an Italian epidemiologic study had reported data supporting the association between LP and alopecia areata and ulcerative colitis, which are considered immune-mediated diseases [7]. A significant association between oral lichen planus (OLP) and thyroid gland disease specifically with hypothyroidism had been reported [8]. It had also been reported that, in Chinese patients with OLP, $21 \%$ have TgAb and 24\% have TMA autoantibodies compared with $1.9 \%$ of healthy control subjects [9].

Recently, Chung PI et al [10] reported a significant association with systemic lupus erythematosus, Sjögren's syndrome, dermatomyositis, vitiligo and alopecia areata among patients with LP.

A case of LPP associated with minimal change nephrotic syndrome have been reported [11]. Authors suggested that this association may reflect common immunological abnormalities. Otherwise, three cases of frontal fibrosing alopecia associated to LPP have been reported [12-14].

In our study, auto-immune diabetes was the most frequent AD associated to LPP (20\%). The association between LPP and diabetes had not been reported before. However, the relationship between LP and diabetes was studied previously. A study concerning the prevalence of OLP in diabetes mellitus according to the type of diabetes [15], found that the prevalence 
of OLP in type 1 diabetic patients was $5.76 \%$, in type $2,2.83 \%$, and $1.82 \%$ in the controls. Giving the fact that DT 1 and OLP are characterized with auto immune phenomena and $\mathrm{T}$ cell immune responses respectively, the authors suggested that the immune system may play a role in the appearance of OLP in patients with DT1.

We suggest that immunological mechanisms mediate the pathogenesis of LPP, as evidenced by association with diseases of altered immunity.

We didn't found studies seeking for the association between LPP and AD but we found a study published recently looking for the association between LPP and thyroid dysfunction [16]. Thyroid disorder was found to be an associated factor in LPP especially hypothyroidism. Levels of thyroid peroxidase antibody in the LPP patients were found to be significantly higher than those of controls. These results support our hypothesis concerning the autoimmune pathogenesis of LPP.

Otherwise, LPP have been reported associated with a non AD which is Hepatitis C. In fact, in the study of Al-Mutairi, 60.6\% of patients with LPP had positive hepatitis $\mathrm{C}$ serology tests. These patients had significantly elevated serum ALT and AST levels, and they were also significantly of older age group and their skin disease was of longer duration compared with patients with negative serology for HCV. In our study, serology tests for Hepatitis B and C were negative for all patients.

\section{Limitations}

Because of the rarity of LPP, and that this study was done in a geographically restricted population, other studies with larger sample sizes from different parts of the world are needed to add further evidence for this association of LPP and AD.

\section{CONCLUSION}

As it has been shown in our study, there is an increased risk multiplied by 22.8 for patients with AD to develop LPP. Patients with LPP are at increased risk of multiple co morbidities such as auto immune diabetes, chronic inflammatory bowel diseases, hypothyroidism, rheumatoid arthritis, anti phospholipid antibody syndrome and Gougerot Sjogren syndrome, which support the key role of autoimmunity in the pathogenesis of LPP. Further researches are required to elucidate the underlying mechanism of the association of these autoimmune co morbid diseases with LPP. Regarding our findings, immunological tests in patients with LPP are required, especially if an $\mathrm{AD}$ is suspected based upon a review of symptoms. We suggest also that LPP patients should be supervised because they could develop AD.

\section{Statement of Human and Animal Rights}

All procedures followed were in accordance with the ethical standards of the responsible committee on human experimentation (institutional and national) and with the Helsinki Declaration of 1975, as revised in 2008 .

\section{Statement of Informed Consent}

Informed consent was obtained from all patients for being included in the study.

\section{REFERENCES}

1. Youssef M, Lahouel I, Héla M, Hadhri R, Akkari H, Mohamed M, et al. Childhood lichen planus pigmentosus. Our Dermatol Online. 2017;8:104-5.

2. Nag F, Ghosh A, Chatterjee G, Choudhary N. Lichen planus pigmentosus: two atypical presentation. Our Dermatol Online. 2013;4:78-9.

3. Kashima A, Tajiri A, Yamashita A, Asada Y, Setoyama M. Two Japanese cases of lichen planus pigmentosus-inversus. Int J Dermatol. 2007;46:740-2.

4. Hassan I, Rather PA, Sajad P. Linear lichen planus pigmentosus and coincidental ipsilateral facial nerve palsy: An unusual observation. Our Dermatol Online. 2012;3:361-2.

5. Mortazavi M, Saad El-Din SA. Bilateral linear lichen planus along the lines of Blaschko: Report of a rare case and brief review. Our Dermatol Online. 2017;8:322-5.

6. Al-Mutairi N, El-Khalawany M. Clinicopathological characteristics of lichen planus pigmentosus and its response to tacrolimus ointment: an open label, non-randomized, prospective study. J Eur Acad Dermatol. Venereol. 2010;24:535-40.

7. Gruppo Italiano Studi Epidemiologi in Dermatologia (GISED). Epidemiological evidence of the association between lichen planus and two immune-related diseases. Alopecia areata and ulcerative colitis. Arch Dermatol 1991;127:688-91.

8. Siponen M, Huuskonen L, Laara E, Salo T. Association of oral lichen planus with thyroid disease in a Finnish population: a retrospective case-control study. Oral Surg Oral Med Oral Pathol Oral Radiol Endod. 2010;110:319-24.

9. Chang JY, Chiang CP, Hsiao CK, Sun A. Significantly higher frequencies of presence of serum autoantibodies in Chinese patients with oral lichen planus. J Oral Pathol Med. 2009;38:48-54.

10. Chung P, Hwang C, Chen Y, Lin MW, Chen TJ, Hua TC, et al. Autoimmune comorbid diseases associated with lichen planus: a nationwide case-control study. J Eur Acad Dermatol Venereol. 2015;29:1570-5.

11. Mancuso G, Berdondini RM. Coexistence of lichen planus pigmentosus and minimal change nephrotic syndrome. Eur J Dermatol. 2009;19:389-90.

12. Rao R, Sarda A, Khanna R, Balachandran C. Coexistence of frontal fibrosing alopecia with lichen planus pigmentosus. Int J Dermatol. 
www.odermatol.com

2014;53:622-4.

13. Dlova NC. Frontal fibrosing alopecia and lichen planus pigmentosus: is there a link? Br J Dermatol. 2013;168:439-42.

14. Berliner JG, McCalmont TH, Price VH, Berger TG. Frontal fibrosing alopecia and lichen planus pigmentosus. J Am Acad Dermatol. 2014;71:e26-7.

15. Petrou-Amerikanou C, Markopoulos AK, Belazi M, Karamitsos D, Papanayotou P. Prevalence of oral lichen planus in diabetes mellitus according to the type of diabetes. Oral Dis. 1998;4:37-40.
16. Karn D, Kc S, Timalsina M. Lichen Planus Pigmentosus: A study for association of Thyroid Dysfunction. Kathmandu Univ Med J (KUMJ). 2016;14:36-40.

Copyright by Monia Youssef, et al. This is an open-access article distributed under the terms of the Creative Commons Attribution License, which permits unrestricted use, distribution, and reproduction in any medium, provided the original author and source are credited.

Source of Support: Nil, Conflict of Interest: None declared. 